\title{
A study on factors affecting the safety zone in ship-to-ship LNG bunkering
}

Sayyoon Park ${ }^{\mathrm{a}, \mathrm{b}, \mathrm{c}}$ and Byongug Jeong ${ }^{\mathrm{b}}$, Joon Young Yoon ${ }^{\mathrm{c}}$ and Jeom Kee

Paik $^{\mathrm{a}, \mathrm{d}, \mathrm{e}, *}$

${ }^{a}$ Department of Naval Architecture and Ocean Engineering, Pusan National University, Busan 46241, Republic of Korea

${ }^{b}$ Department of Naval Architecture, Ocean and Marine Engineering, University of Strathclyde, Glasgow G4 OLZ, UK

${ }^{c}$ Gas \& Safety R\&D Department, Daewoo Ship Building \& Marine Engineering (DSME), Geo-je 53302, Republic of Korea

${ }^{d}$ Department of Mechanical Engineering, University College London, London WC1E 7JE, $U K$

'The Korea Ship and Offshore Research Institute (The Lloyd's Register Foundation Research Centre of Excellence), Pusan National University, Busan 46241, Republic of Korea

*Corresponding author. Tel.: +82 51510 2429; fax: +82 51518 7687. E-mail address: jeompaik@pusan.ac.kr

\begin{abstract}
The objective of this paper is to examine the characteristics of leaked-gas dispersion in ship to ship LNG bunkering, thereby providing an insight towards determining the appropriate level of safety zones in which the potential hazards pertinent to LNG bunkering are required to be minimized. For this purpose, parametric studies are undertaken in various operational and environmental conditions, with varying geometry of the bunkering ship, gas leak rate, wind speed and wind direction. The study applies computational fluid dynamics (CFD) simulations for case-specific scenarios where a hypothetical LNG bunkering ship with a capacity of $5,100 \mathrm{~m}^{3}$ in tank space is considered to refuel two typical types of large-ocean going vessels: an 18,000 TEU containership
\end{abstract}


and a 319,000 DWT very large crude oil carrier. Research findings reveal that the gas leak rate and leak duration would be the parameters with the most influence in determining the extent of safety zones. It is pointed out that other parameters such as ship geometry, wind speed, and wind direction are also influential parameters. Details of the computations and discussions are presented.

Keywords: LNG fuelled ship; LNG bunkering; Ship to ship LNG bunkering; Gas leaks; Safety zone

\section{Introduction}

LNG (liquefied natural gas) has been acknowledged as one of the most credible substitutes for conventional liquid marine fuel sources in response to stringent international/local regulations (Aymelek et al. 2015; IGU 2017; IMO 2014). Since the world's first LNG fuelled ship (LFS) emerged in 2000, the market for LFS's has steadily grown over the past two decades. As of 2017, more than two hundred LFS's have been either contracted or operated (Ship \& Bunker 2017). This trend brings about the optimistic anticipation that LFSs will account for $30 \%$ of new global shipbuilding projects by 2025 (Lloyd's Register 2012).

LNG bunkering, an essential process for LFSs, can be technically categorized by the following three methods: truck to ship (TTS), ship to ship (STS) and pipeline to ship (PTS). Until now, TTS has been the most common method due to its high accessibility and operating convenience. Since LFSs continue to grow in size, STS and PTS have drawn more attention from stakeholders who strive to find practicable bunkering methods to meet the demands of increasing bunkering capacity. Despite almost unlimited bunkering capacity, the PTS method is somewhat constrained by the need for land 
acquisition to build a bunkering infrastructure. These problems include not only social but also economic burdens. On the other hand, STS has emerged as the most practical way to ensure high bunkering volumes and good access without regional restrictions (Ship-technology 2017; Schuler 2017; Ship \& Bunker 2016).

LNG, on the other hand, is a cryogenic liquid and typically stored in an adiabatic storage tank. Unwanted events related to LNG release from any part of the system may lead to several potential threats such as asphyxiation, cryogenic burns, structural damage, rapid phase transitions (RPT) and even fires and explosions when the leaked gas meets a source of ignition (ISO 2015; Crowl and Louvar 2001). Moreover, these initial incidents often lead to a larger chain of accidents (IMO 2015; Lasse 2015).

With the advent of LNG-fuelled ships since 2000, International Maritime Organization (IMO) has introduced an 'International Code of Safety for Ships using Gases or other Low-flashpoint Fuels' (IGF Code) in an effort to preserve the safety of these new types of commercial ships. Given that LNG bunkering is an inevitable process which may pose higher risk than the conventional bunkering for oil products, the IGF Code does not deal with specific guidelines for enhancing the safety of LNG bunkering (IMO 2017). As a result, safety insights into LNG bunkering have been divisive.

To ensure the safety of personnel during the LNG bunkering, ISO/TS 18683 (ISO 2015) recommends establishing a safety zone within which the access of all non-essential personnel for the bunkering is to be stringently restricted. However, the ISO standards are limited to the provision of general information and do not offer quantified guidance. Local regulations, class rules and industry guidelines are primarily the same as the ISO standards for the safety of LNG bunkering. Jeong et al. (2017b), however, pointed out the need for more quantified guidelines to determine the extent of safety zones for LNG bunkering, addressing the pitfalls of the current regulations. The study emphasized that 
the development of quantified guidelines is an urgent and essential task for safer bunkering.

Meanwhile, there have been several studies investigating the risk of marine LNG systems. Davies and Fort (2014) in Lloyd's Register group have examined the likelihood of LNG release. Elsayed et al. (2009) applied a multi-attribute risk assessment methodology to LNG carriers during loading/offloading at terminals. Arnet (2014) carried out a quantitative risk assessment of LNG bunkering operations, while DNVGL (2014) investigated the risk pertinent to probable leakage accidents with the aid of PHAST software. Sun et al. (2017) performed CFD simulations to estimate the consequential levels of LNG spillage during STS bunkering. Jeong et al. (2017a) investigated the risk of a high-pressure fuel gas supply system (HP-FGSS) fitted to a conceptual LNG fuelled ore carrier from the standpoint of structural safety against vapour cloud explosions. Using FLACS CFD tool, Pedersen and Midda (2012) conducted a series of simulations for vented gas explosions. Fan et al. (2016) have estimated the proper extent of the safety zone of an LNG bunkering vessel with the LNG storage capacity of $10,000 \mathrm{~m}^{3}$ which is transferred to an LNG fuelled 18,000 TEU container ship.

Despite the voluminous research, their focuses were too case-specific to obtain a general insight into major or minor elements that may contribute to influencing the safety of LNG bunkering, thereby determining the extent of the safety zone. Instead, research findings from those studies are more relevant to individual circumstances than general ones. As a result, in the course of investigating the risk of STS LNG bunkering and quantifying the extent of the safety zone, IMO member states have yet to develop their own regulations applicable to all LNG fuelled ships.

The shortcomings of the previous studies and current regulations have motivated the carrying out of this paper. In this context, the present research was focused on 
investigating characteristics of leaked-gas dispersion in STS LNG bunkering in order to identify the significant parameters influencing the extent of the safety zone for LNG bunkering. Case studies were carried out with two typical ocean-going cargo ships: a container ship with the capacity to carry 18,000 twenty-foot equivalent units (TEUs) and a very large crude-oil carrier (VLCC) with 319,000 dead weight tonnage (DWT). These ships were assumed to be subjected to STS bunkering through an LNG bunkering vessel with the capacity to store and carry $5,100 \mathrm{~m}^{3}$. The risk assessment followed a generic and deterministic approach to estimate the level of safety zones for the case ships. By identifying the critical parameters influencing the enlargement of the safety zone, this work is aimed at providing the insights of ship-owners and flag authorities into the estimation of appropriate safety zones during LNG bunkering, playing a role as a preliminary study in the hopes of contributing to enhancing current international regulations.

\section{Procedure of the Study}

\subsection{Parametric studies}

During LNG bunkering, an unwanted LNG leakage may happen in the form of jet release which would form flammable gas disperses across surroundings (ISO 2015). Therefore, the personnel within an area where the level of gas concentration is high enough to be flammable are deemed to be at risk.

To understand the physical behaviour of LNG leakage and dispersion, this paper performs a series of parametric analysis where the influence of various parameters on the characteristics of leaked-gas dispersion and the extent of safety zones is investigated. Figure 1 shows the procedure applied for the present study. 


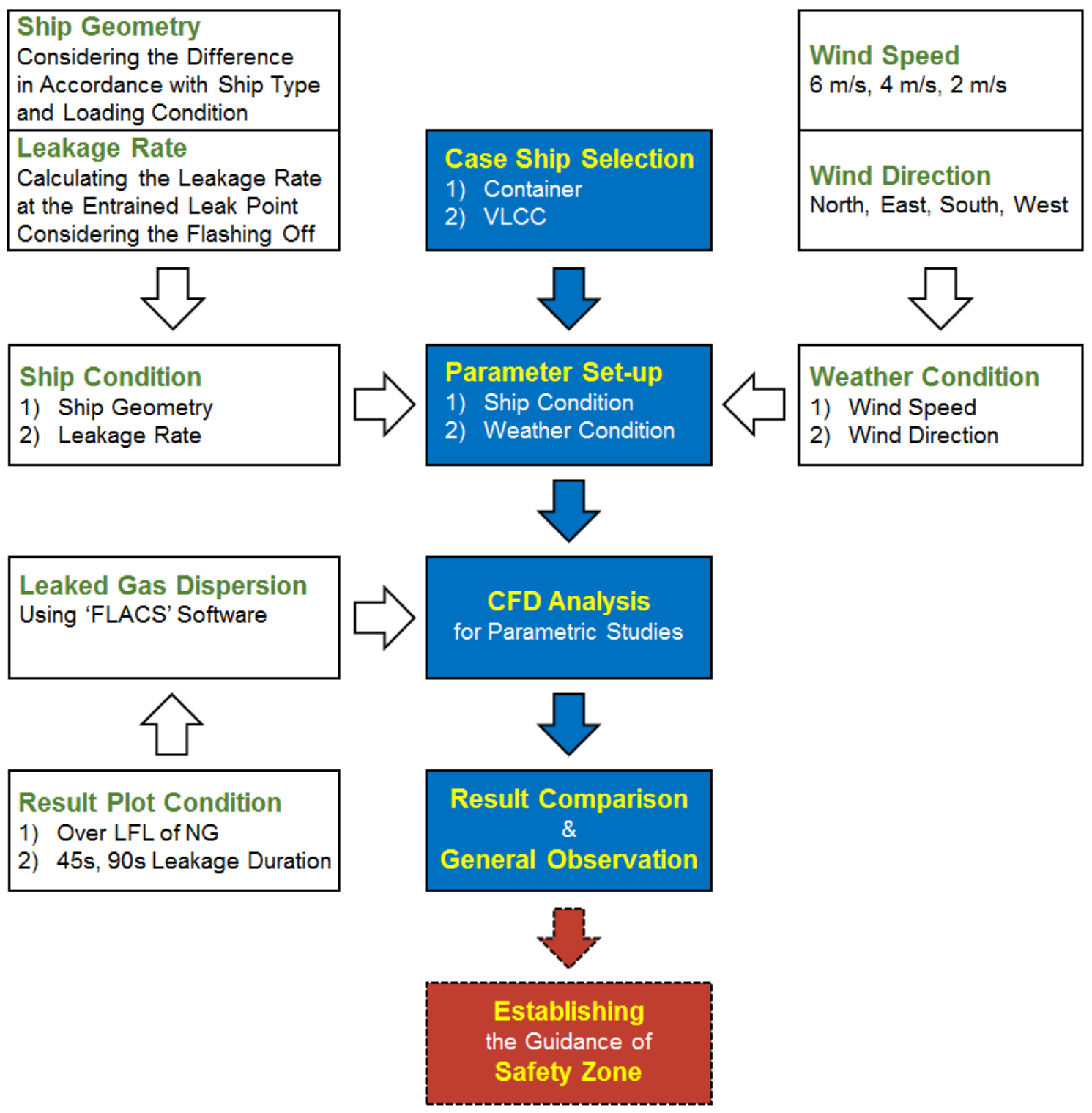

Figure 1. Flow of the present study.

Four parameters, namely ship geometry, leakage rate, wind speed, and winder direction are selected for the parametric studies. Different structural outlines of the two case ships are applied to investigate the geometric sensitivity on gas dispersion, while their loading conditions are also considered accordingly. Several leak scenarios are considered to investigate the relationship between the leakage rate and the extent of the safety zone. Various wind speeds and directions are considered to examine their parametric influences on the safety zone. In this regard, wind speeds are varied at $6 \mathrm{~m} / \mathrm{s}$ (harsh), $4 \mathrm{~m} / \mathrm{s}$ (normal) and $2 \mathrm{~m} / \mathrm{s}$ (mild), whereas the four representative wind directions, 
namely North, East, South, and West are considered.

The impacts of gas dispersion in various individual leak scenarios are assessed using FLACS Ver. 10.5, a computational fluid dynamics (CFD) method (Gant and Hoyes 2010). Based on past studies and software guidelines (Gexcon AS 2016; Hjertager 1985; Patankar 1980; Launder \& Spalding 1974), the Reynolds averaged Naiver-Stokes equations coupled with the $\mathrm{k}-\varepsilon$ model for turbulence equations are applied for the present simulations.

The critical distance and area in relation to the flammable gas dispersion are defined where the gas concentration is higher than LFL (lower flammable limit) of natural gas. According to DNV guidelines (DNV 2012), the leak duration is assumed to be 90 seconds corresponding to the working time of the ESD valve (60 seconds for detection and activation, 30 seconds for quarantine). Since the effects of gas dispersion may vary depending on the passage of time, the critical distances and areas are investigated at two leak durations, i.e., with $45 \mathrm{~s}$ and $90 \mathrm{~s}$. The annual average temperature is assumed to be $15{ }^{\circ} \mathrm{C}$ for the CFD modelling input values. In all cases, the direction of the initial leakage is considered to be towards the East. The details in simulation conditions are summarized in Table 1.

Table 1. General information of the CFD modelling condition.

\begin{tabular}{c|c|c|c|c|c}
\hline $\begin{array}{c}\text { Analysis } \\
\text { Duration }\end{array}$ & $\begin{array}{c}\text { Leakage } \\
\text { Duration }\end{array}$ & $\begin{array}{c}\text { Wind Build-up } \\
\text { Time }\end{array}$ & $\begin{array}{c}\text { Reference } \\
\text { Height } \\
\text { of the Wind }\end{array}$ & $\begin{array}{c}\text { Ambient } \\
\text { Temperature }\end{array}$ & $\begin{array}{c}\text { Leakage Direction } \\
\text { at the Initial Leak } \\
\text { Hole }\end{array}$ \\
\hline 110 Seconds & 90 Seconds & 10 Seconds & $10 \mathrm{~m}$ & $15{ }^{\circ} \mathrm{C}$ & West $\rightarrow$ East \\
\hline $\begin{array}{c}\text { Simulation } \\
\text { Volume Sizes } \\
{[\mathbf{m}]}\end{array}$ & $\begin{array}{c}\text { Boundary } \\
\text { Condition } \\
{[\mathbf{X}, Y, Z]}\end{array}$ & $\begin{array}{c}\text { Courant- } \\
\text { Friedrichs-Levy } \\
\text { Number }\end{array}$ & $\begin{array}{c}\text { Grid Size } \\
\text { [minimum] }\end{array}$ & $\begin{array}{c}\text { Grid Size } \\
\text { [maximum] }\end{array}$ & \\
\hline $\begin{array}{c}(800,380, \\
200)\end{array}$ & $\begin{array}{c}\text { Wind(Outflow) } \\
\&\end{array}$ & $\begin{array}{c}\text { CFLV:5 20 } \\
\text { CFLC:1 2 }\end{array}$ & $0.28 \mathrm{~m}$ & $20 \mathrm{~m}$ & \\
\hline \hline
\end{tabular}

From the simulations, the critical distance and area for each case can be observed. 
The measured critical distances and areas are directly used to represent the extent of the safety zones. These results obtained from various scenarios are then collected and plotted in the diagram as a convenient format for comparison across the scenarios. This paper then investigates the parametric sensitivity in determining the extent of the safety zone.

\subsection{Technical reference of $C F D$}

\subsubsection{Governing equation}

Mathematical models for compressible fluid flow used in FLACS software are described as below.

Conservation of mass:

$$
\frac{\partial}{\partial t}\left(\beta_{v} \rho\right)+\frac{\partial}{\partial x_{j}}\left(\beta_{j} \rho u_{j}\right)=\frac{\dot{r}}{V}
$$

where $\beta_{j}$ is the porosity, $u_{j}$ is the mean velocity $[\mathrm{m} / \mathrm{s}], \beta_{v}$ is the volume porosity, $r$ is the mass rate $[\mathrm{kg} / \mathrm{s}], \rho$ is density $\left[\mathrm{kg} / \mathrm{m}^{3}\right]$ and $V$ is the volume $\left[\mathrm{m}^{3}\right]$.

Momentum equation:

$$
\frac{\partial}{\partial t}\left(\beta_{v} \rho u_{i}\right)+\frac{\partial}{\partial x_{j}}\left(\beta_{j} \rho u_{i} u_{j}\right)=-\beta_{v} \frac{\partial p}{\partial x_{i}}+\frac{\partial}{\partial x_{j}}\left(\beta_{j} \sigma_{i j}\right)+F_{o, i}+F_{w, i}+\beta_{v}\left(\rho-\rho_{0}\right) g_{i}
$$

where $F_{w, i}$ is the flow resistance due to walls, $\sigma_{i j}$ is the stress tensor, $F_{o, i}$ is the flow resistance due to sub-grid obstructions, $p$ is the absolute pressure $[\mathrm{Pa}], x$ is the concentration ratio of gas $[\mathrm{mol} / \mathrm{mol}]$ and $t$ is the time [s].

\subsubsection{Turbulence model}

Turbulence is modelled by a two-equation model, the $\mathrm{k}-\varepsilon$ model. It is an eddy viscosity 
model that solves two additional transport equations; one for turbulent kinetic energy and the other for dissipation of turbulent kinetic energy. Following Boussinesq eddy viscosity assumption, an eddy viscosity models the Reynolds stress tensor as follows:

$$
-\rho u_{i}^{\prime \prime} u_{j}^{\prime \prime}=\mu_{e f f}\left(\frac{\partial u_{i}}{\partial x_{j}}+\frac{\partial u_{j}}{\partial x_{i}}\right)-\rho \frac{2}{3} k \delta_{i j}
$$

where $\rho$ is the density $\left[\mathrm{kg} / \mathrm{m}^{3}\right], u_{i}, u_{j}$ are the mean velocities $[\mathrm{m} / \mathrm{s}], \mu_{e f f}$ is the effective viscosity $[\mathrm{Pa} \cdot \mathrm{s}], x_{i}, x_{j}$ are the concentration ratios of gas $[\mathrm{mol} / \mathrm{mol}], k$ is the turbulent kinetic energy $\left[\mathrm{m}^{2} / \mathrm{s}^{2}\right]$ and $\delta_{i j}$ is the Kronecker delta function.

A few constants are included in the equations mentioned above. In FLACS code, the set of constants indicated in Table 2 are used as discussed by Launder and Spalding (1974).

Table 2. A set of constants used for the turbulence model.

\begin{tabular}{|c|c|c|c|}
\hline$c_{\mu}$ & $c_{1 \varepsilon}$ & $c_{2 \varepsilon}$ & $c_{3 \varepsilon}$ \\
\hline 0.09 & 1.44 & 1.92 & 0.8 \\
\hline
\end{tabular}

\subsubsection{Wall functions}

Boundary layers are regions in the flow field close to walls and obstructions where there are steep gradients and peak values for turbulent kinetic energy and its dissipation rate. Very close to the wall surface viscous forces dominate over inertial effects. The motivation for using wall-functions is to model the influence of the wall at a point a certain distance from the wall. 


\subsubsection{Wind boundary}

Wind boundary reproduces the properties of the atmospheric boundary layer close to Earth's surface. Monin \& Obukhov developed a theory to explain buoyancy effects on the atmospheric boundary layer and defined a characteristic length scale:

$$
L=-\frac{\rho_{a} c_{p} T_{a} u^{* 3}}{\kappa g H_{s}}
$$

where, $T$ is the turbulent, $\kappa$ is the Von Karman constant, $u^{*}$ is the friction velocity $[\mathrm{m} / \mathrm{s}$ ], $g$ is the gravitational acceleration $\left[\mathrm{m} / \mathrm{s}^{2}\right]$ and $H_{s}$ is the sensible heat flux from the surface. The Monin-Obukhov length is a measure of the stability of the atmospheric boundary layer.

\section{Parametric Studies}

\subsection{Target ships}

The specification of the target ships and the bunkering vessel are summarized in Table 3 . The freeboard of the container ship is $17.2 \mathrm{~m}$, while that of the VLCC is $9.7 \mathrm{~m}$. In the full load condition, the depth of the container ship, including the height of the four layers of stacked container cargo, is estimated at $48.78 \mathrm{~m}$.

According to the Ship to Ship Transfer Guide for Petroleum, Chemicals and Liquefied Gases (CDI et al. 2013), the fender size between the LFS and bunkering vessel can be calculated using Equation (5). As indicated in Table 4, the results of calculations reveal that the 4 pieces $(3.3 \mathrm{~m} \times 6.5 \mathrm{~m})$ of fender should be arranged accordingly. Figures 2 to 4 show the geometry model of the case ships and the bunkering vessel.

$$
C=\frac{2 \times(\text { Displacement of the ship } A) \times(\text { Displacement of the ship } B)}{(\text { Displacement of the ship } A)+(\text { Displacement of the ship } B)}
$$


Table 3. General information of the target ships

\begin{tabular}{|c|c|c|c|}
\hline Principle Particulars & $\begin{array}{c}\text { 18,000 TEU } \\
\text { Container Ship } \\
\text { (Case Ship 1) }\end{array}$ & $\begin{array}{c}\text { 319,000 DWT } \\
\text { VLCC } \\
\text { (Case Ship 2) }\end{array}$ & $\begin{array}{c}5,100 \mathrm{~m}^{3} \\
\text { LNG Bunkering } \\
\text { Vessel } \\
\end{array}$ \\
\hline$L \times B \times D x d[m]$ & $399 \times 58.6 \times 33.2 \times 16.0$ & $336 \times 60 \times 30.5 \times 20.8$ & $107.6 \times 18.4 \times 9 \times 4.7$ \\
\hline $\begin{array}{c}\text { LNG Fuel Tank Volume } \\
{\left[\mathrm{m}^{3}\right]}\end{array}$ & \multicolumn{2}{|c|}{ 6,000 (full) / 5,100 (Operating) } & 5,100 \\
\hline
\end{tabular}

[Note] L=Length, $\mathrm{B}=$ Breadth, $\mathrm{D}=$ Depth and $\mathrm{d}=\mathrm{draft}$

Table 4. Results of Fender size calculations.

\begin{tabular}{|c|c|c|c|c|}
\hline $\begin{array}{c}\text { Criteria: } \\
\text { Berthing Coefficient } \\
\text { (C) } \\
\text { [Tonnes] }\end{array}$ & $\begin{array}{l}\text { Suggested } \\
\text { Fenders } \\
\text { [Quantity] }\end{array}$ & $\begin{array}{c}\text { Typical HP } \\
\text { Pneumatic Fender } \\
(50 \mathrm{kPa}) \\
{[\mathrm{m}]}\end{array}$ & $\begin{array}{c}\text { Calculated (C): } \\
\text { Case Ship 1 } \\
\text { (Container Ship) } \\
\text { [Tonnes] }\end{array}$ & $\begin{array}{c}\text { Calculated (C): } \\
\text { Case Ship } 2 \\
\text { (VLCC) } \\
\text { [Tonnes] }\end{array}$ \\
\hline 10,000 & 3 or more & $2.5 \times 5.5$ & \multirow{2}{*}{14,760} & \multirow{2}{*}{14,640} \\
\hline 30,000 & 4 or more & $3.3 \times 6.5$ & & \\
\hline
\end{tabular}

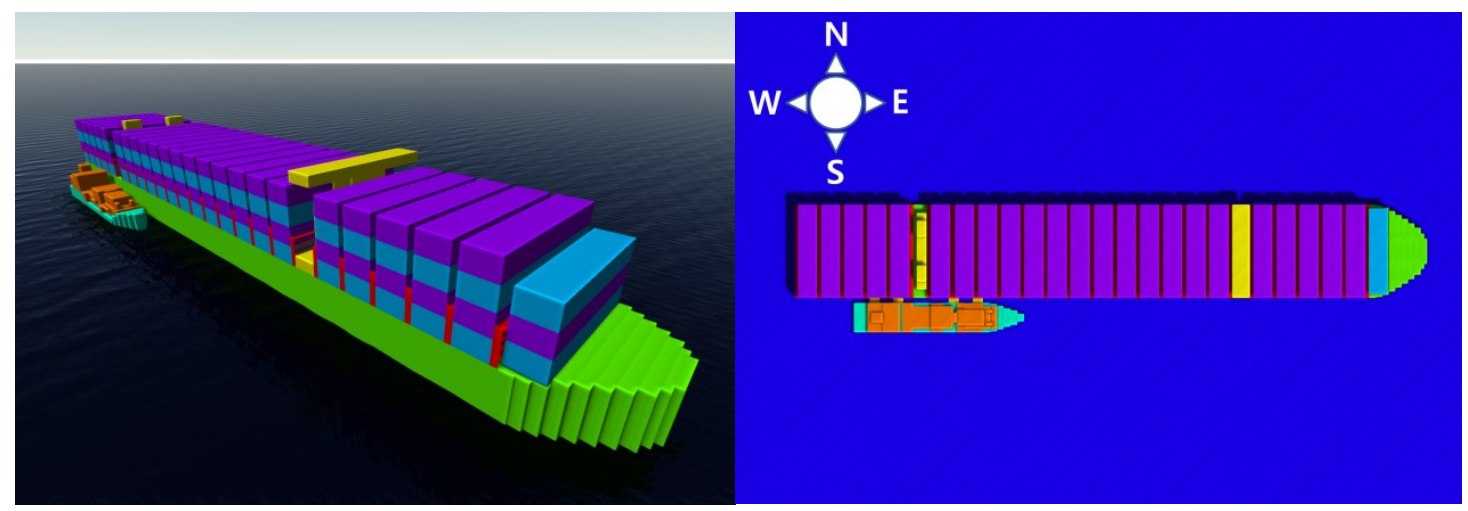

Figure 2. Geometry of target ship 1 (container ship) in full load condition.

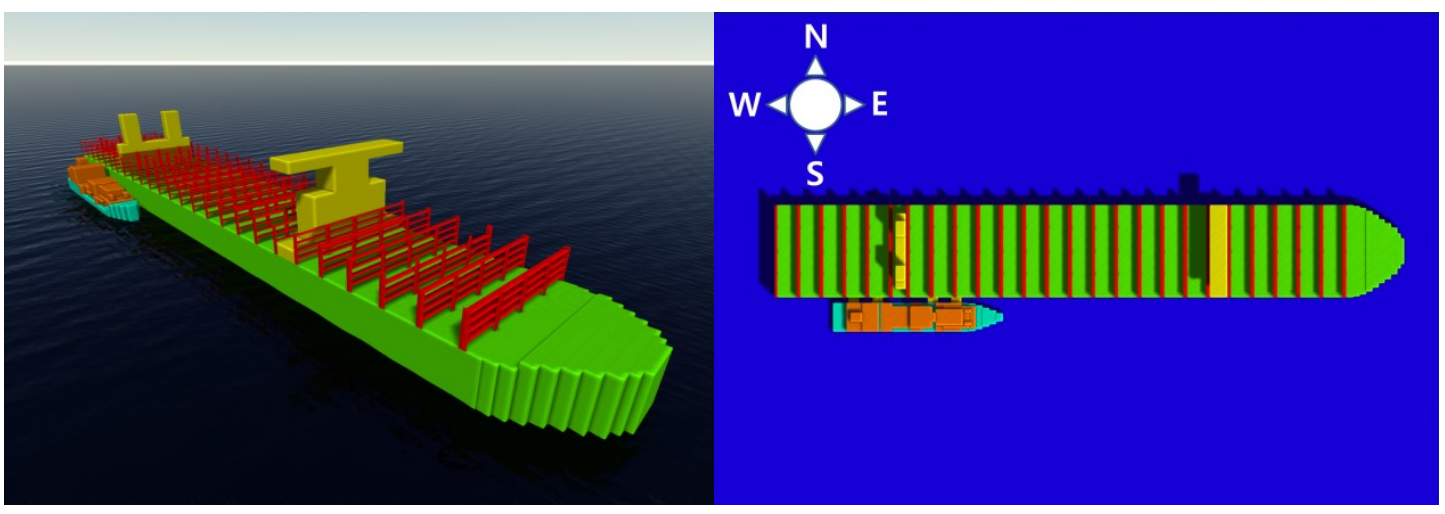

Figure 3. Geometry of target ship 1 (container ship) in ballast condition. 


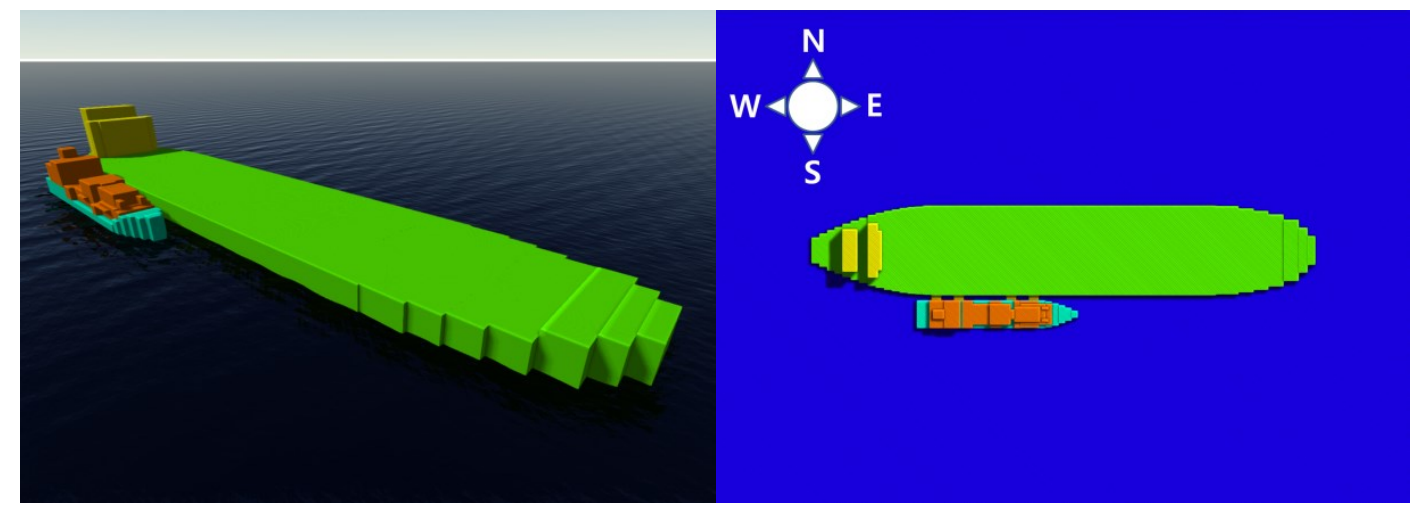

Figure 4. Geometry of target ship 2 (VLCC class tanker).

\subsection{Effect of leak rate (leak amount)}

The gauge pressure inside the LNG bunkering system is considered at $3 \mathrm{bar}(\mathrm{g})$, and the boiling point of LNG at the pressure is about $-141{ }^{\circ} \mathrm{C}$ (Jeong et al. 2017b; DNV 2012).

The density of LNG at the proposed pressure and temperature is assumed to be $392 \mathrm{~kg} / \mathrm{m}^{3}$. The discharge coefficient is taken as 0.62 for a sharp-edged leakage hole. Using Equation (6) below, the leakage rate at the initial leakage point can be calculated.

$$
Q=C \times A \times \sqrt{2 \times \rho \times p_{g}}
$$

where $Q$ is the leak rate $[\mathrm{kg} / \mathrm{s}], C$ is the discharge coefficient, $A$ is the cross sectional area of the leak point $\left[\mathrm{m}^{2}\right], \rho_{L N G}$ is the density of $\mathrm{LNG}\left[\mathrm{kg} / \mathrm{m}^{3}\right]$, and $P_{g}$ is the guague pressure inside the pipe $[\mathrm{Pa}]$.

Table 5. Leak rate depending on leak hole (size).

\begin{tabular}{ccccc}
\hline $\begin{array}{c}\text { Leak Hole } \\
\text { Diameter } \\
{[\mathbf{m m}]}\end{array}$ & $\begin{array}{c}\text { Discharge } \\
\text { Coefficient }\end{array}$ & $\begin{array}{c}\text { Density } \\
{\left[\mathbf{k g} / \mathbf{m}^{3}\right]}\end{array}$ & $\begin{array}{c}\text { Leak Area } \\
{\left[\mathbf{m}^{2}\right]}\end{array}$ & $\begin{array}{c}\text { Leak Rate } \\
{[\mathbf{k g} / \mathbf{s}]}\end{array}$ \\
\hline 50 & & & $1.96 \mathrm{E}-03$ & $1.87 \mathrm{E}+01$ \\
150 & 0.62 & 392 & $1.77 \mathrm{E}-02$ & $1.68 \mathrm{E}+02$ \\
250 & & & $4.91 \mathrm{E}-02$ & $4.66 \mathrm{E}+02$ \\
\hline
\end{tabular}


Due to the high pressure in operation, an LNG leak is likely to be a jet. As a realistic phenomenon, part of the leaked liquid would immediately evaporate under the ambient condition, which can be described as the 'flashing effect'. This effect is generally determined by the properties of the material and operating conditions such as storage temperature, the typical boiling point, the heat capacity of the gas and the latent heat of evaporation.

In this context, as described in Figure 5, the concept of flash utility is introduced to supplement the limitations of CFD where it is technically impossible to model and simulate the entire process ranging from the initial LNG leak, evaporation and gas dispersion at once. Meanwhile, the flash utility provides the most realistic and technically feasible alternative to calculate the leak area, flow rate, and equivalent rate (fuel concentration) at $\mathrm{X}_{\mathrm{f}}$ where the initial LNG leak is completely vaporized. Then, the simulations directly deal with the effect of gas dispersion with the flow of gas-air mixture estimated at $\mathrm{X}_{\mathrm{f}}$

Calculation results are summarized in Table 6. It is noted that the leak rate at the initial hole represents the pure LNG leak rate, whereas the flow rate at $\mathrm{X}_{\mathrm{f}}$ represents the flow of the gas mixture added with air which is significantly higher than the initial flow of the leaked LNG.

On the other hand, the equivalence ratio represents the mixture ratio (concentration ratio) between the gas and air at $\mathrm{X}_{\mathrm{f}}$. It can be defined as the ratio of the mass of fuel to the mass of oxygen, divided by the ratio of the mass of fuel to the mass of oxygen at the stoichiometric concentration as indicated in Equation (7). In this paper, the equivalence ratio value at $\mathrm{X}_{\mathrm{f}}$ is calculated as 7.39 .

$$
\text { Equivalence Ratio }=\frac{\left(\text { mass }_{\text {fuel }} / \text { mass }_{\text {oxygen }}\right)}{\left(\text { mass }_{\text {fuel }} / \text { mass }_{\text {oxygen }}\right)_{\text {stoichiometric }}}
$$




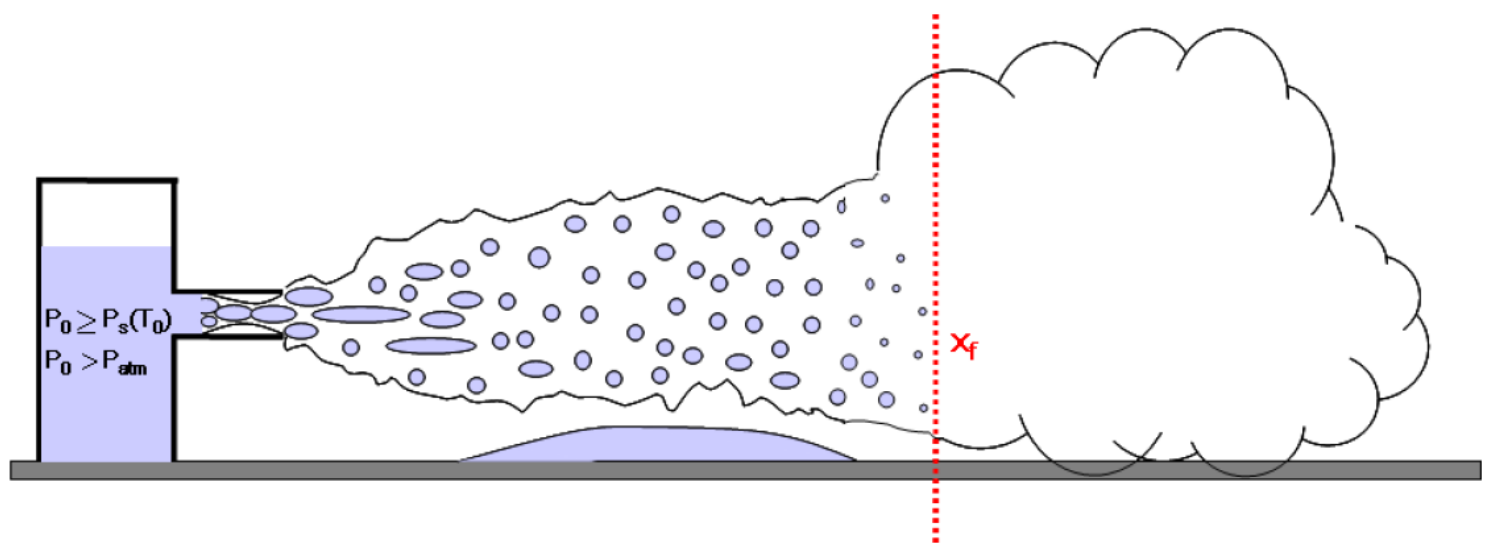

Figure 5. Flash description in a liquefied gas leakage accident (Gexcon 2017).

Table 6. Results of flow rate calculations at the entrained point using flash utility.

\begin{tabular}{cccccc}
\hline $\begin{array}{c}\text { Leak Hole } \\
\text { Diameter } \\
{[\mathbf{m m}]}\end{array}$ & $\begin{array}{c}\text { Ambient } \\
\text { Temperature } \\
{\left[{ }^{\circ} \mathrm{C}\right]}\end{array}$ & $\begin{array}{c}\text { Equivalence } \\
\text { Ratio at } \mathbf{X}_{\mathbf{f}}\end{array}$ & $\begin{array}{c}\text { Distance } \\
\text { from Initial Leak Hole } \\
\text { to Entrained Leak Point } \\
{[\mathbf{m}]}\end{array}$ & $\begin{array}{c}\text { Jet Leak } \\
\text { Area } \\
\text { at } \mathbf{X}_{\mathbf{f}} \\
{\left[\mathbf{m}^{2}\right]}\end{array}$ & $\begin{array}{c}\text { Flow Rate } \\
\text { at } \mathbf{X}_{\mathbf{f}} \\
{[\mathbf{k g} / \mathbf{s}]}\end{array}$ \\
\hline 50 & & & $6.24 \mathrm{E}+00$ & $1.39 \mathrm{E}+00$ & $6.22 \mathrm{E}+01$ \\
150 & 15 & 7.39 & $1.87 \mathrm{E}+01$ & $1.25 \mathrm{E}+01$ & $5.60 \mathrm{E}+02$ \\
250 & & & $3.12 \mathrm{E}+01$ & $3.47 \mathrm{E}+01$ & $1.55 \mathrm{E}+03$ \\
\hline
\end{tabular}

To investigate the effect of the leakage amount on determining the level of the safety zone, two parameters, namely leak rate, and its duration are varied while the wind speed and direction are fixed at $6 \mathrm{~m} / \mathrm{s}$ and north. Table 7 indicates the relationship between the leakage amount and maximum critical distance (represented by the maximum length of gas reaching the flammable level) and the critical area (designated by the gas dispersion area within the flammable level). Given the lack of quantified guidelines safety zone is to be established in accordance with the level of the maximum critical distance and the area, the results of analysis reveal that both high leak rate and prolonged leak isolation would lead to extending the safety zone.

On the other hand, research results also show that the VLCC tanker in open surrounding condition tends to have a higher level of maximum critical distances and areas than the container ship in full load condition (in congested surrounding condition). 
This means that the severity of flammable dispersion is higher in open spaces than in congested spaces; it can be perceived that the gas spreads out quickly and widely in open spaces while congested surroundings are more likely to capture the gas within the limited space than open surroundings. As a result, the maximum critical distance and area subject to the safety zone are more extensive for open spaces than congested spaces in general. It is also important to mention that the container ship in the full load condition is relatively more influenced by the leakage amount than the VLCC tanker. This points out that the congestion level is also a sensitive parameter to extend the safety zone.

Table 7. Maximum critical distance under various leak amounts for container shipVLCC tanker

\begin{tabular}{|c|c|c|c|c|c|c|}
\hline $\begin{array}{c}\text { Leak Hole } \\
\text { Diameter } \\
{[\mathrm{mm}]}\end{array}$ & $\begin{array}{c}\text { Leakage } \\
\text { Duration } \\
\text { [sec] }\end{array}$ & Geometry & $\begin{array}{c}\text { Maximum } \\
\text { Critical } \\
\text { Distance } \\
\text { [m] }\end{array}$ & $\begin{array}{c}\text { Critical } \\
\text { Area } \\
{\left[\mathbf{m}^{2}\right]}\end{array}$ & \multicolumn{2}{|c|}{ Dispersion Plot } \\
\hline \multirow{4}{*}{$\begin{array}{c}250 \\
(466.0 \mathrm{~kg} / \mathrm{s})\end{array}$} & \multirow{2}{*}{45} & $\begin{array}{l}\text { Container (Full } \\
\text { Load Cond) }\end{array}$ & 204 & 9,831 & \multicolumn{2}{|c|}{$0 \mathrm{~m} 200 \mathrm{~m}$ • Entrained Leak Point } \\
\hline & & VLCC & 266 & 25,478 & & Container \\
\hline & \multirow{2}{*}{90} & $\begin{array}{c}\text { Container (Full } \\
\text { Load Cond) }\end{array}$ & 380 & 23,665 & & (Full Loading) \\
\hline & & VLCC & 399 & 47,991 & & VLCC \\
\hline \multirow{4}{*}{$\begin{array}{c}150 \\
(168.0 \mathrm{~kg} / \mathrm{s})\end{array}$} & \multirow{2}{*}{45} & $\begin{array}{l}\text { Container (Full } \\
\text { Load Cond) }\end{array}$ & 205 & 3,311 & \multirow{4}{*}{\multicolumn{2}{|c|}{ सुत्रुस }} \\
\hline & & VLCC & 275 & 12,098 & & \\
\hline & \multirow{2}{*}{90} & $\begin{array}{l}\text { Container (Full } \\
\text { Load Cond) }\end{array}$ & 326 & 10,690 & & \\
\hline & & VLCC & 318 & 13,095 & & \\
\hline \multirow{4}{*}{$\begin{array}{c}50 \\
(18.7 \mathrm{~kg} / \mathrm{s})\end{array}$} & \multirow{2}{*}{45} & $\begin{array}{l}\text { Container (Full } \\
\text { Load Cond) }\end{array}$ & 75 & 473 & \multirow{4}{*}{$\rightarrow$} & $0 \mathrm{~m} 200 \mathrm{~m}$ \\
\hline & & VLCC & 175 & 1,839 & & \\
\hline & \multirow{2}{*}{90} & $\begin{array}{l}\text { Container (Full } \\
\text { Load Cond) }\end{array}$ & 171 & 1,638 & & \\
\hline & & VLCC & 223 & 2,930 & & \\
\hline
\end{tabular}

\subsection{Effect of wind speed}

Given the fact that wind speed varies with time and area, a parametric analysis was carried out to investigate the effect of wind speed. As setting up new conditions where a 
maximum leak rate of $466.0 \mathrm{~kg} / \mathrm{s}$ (250 mm leak hole dia.) and the Northerly wind direction with two leak durations, $45 \mathrm{~s}$, and $90 \mathrm{~s}$ were considered to be the fixed parameters. Under this condition, three wind speeds - $6 \mathrm{~m} / \mathrm{s}$ (harsh), $4 \mathrm{~m} / \mathrm{s}$ (normal) and $2 \mathrm{~m} / \mathrm{s}$ (mild) were applied as variables.

Table 8. Maximum critical distance under various wind speeds for container shipVLCC tanker

\begin{tabular}{|c|c|c|c|c|c|c|}
\hline $\begin{array}{c}\text { Wind } \\
\text { Speed } \\
{[\mathrm{m} / \mathbf{s}]}\end{array}$ & $\begin{array}{c}\text { Leakage } \\
\text { Duration } \\
\text { [sec] }\end{array}$ & Geometry & $\begin{array}{c}\text { Maximum } \\
\text { Critical } \\
\text { Distance } \\
\text { [m] }\end{array}$ & $\begin{array}{c}\text { Critical } \\
\text { Area } \\
{\left[\mathbf{m}^{2}\right]}\end{array}$ & \multicolumn{2}{|c|}{ Dispersion Plot } \\
\hline \multirow{4}{*}{6} & \multirow{2}{*}{45} & $\begin{array}{l}\text { Container (Full } \\
\text { Load Cond) }\end{array}$ & 204 & 9,831 & \multicolumn{2}{|c|}{$0 \mathrm{~m} 200 \mathrm{~m}$ Entrained Leak Point } \\
\hline & & VLCC & 266 & 25,478 & & Container \\
\hline & \multirow{2}{*}{90} & $\begin{array}{l}\text { Container (Full } \\
\text { Load Cond) }\end{array}$ & 380 & 23,665 & & (Full Loading) \\
\hline & & VLCC & 399 & 47,991 & & VLCC \\
\hline \multirow{4}{*}{4} & \multirow{2}{*}{45} & $\begin{array}{l}\text { Container (Full } \\
\text { Load Cond) }\end{array}$ & 291 & 15,415 & \multirow{4}{*}{\multicolumn{2}{|c|}{ इन كै? }} \\
\hline & & VLCC & 301 & 32,000 & & \\
\hline & \multirow{2}{*}{90} & $\begin{array}{l}\text { Container (Full } \\
\text { Load Cond) }\end{array}$ & 403 & 25,730 & & \\
\hline & & VLCC & 389 & 57,464 & & \\
\hline \multirow{4}{*}{2} & \multirow{2}{*}{45} & $\begin{array}{l}\text { Container (Full } \\
\text { Load Cond) }\end{array}$ & 336 & 36,845 & \multirow{4}{*}{\multicolumn{2}{|c|}{$0 \mathrm{~m} \quad 200 \mathrm{~m}$}} \\
\hline & & VLCC & 310 & 52,071 & & \\
\hline & \multirow{2}{*}{90} & $\begin{array}{c}\text { Container (Full } \\
\text { Load Cond) }\end{array}$ & 454 & 59,694 & & \\
\hline & & VLCC & 482 & 109,581 & & \\
\hline
\end{tabular}

Results show that, in the mild wind conditions, the maximum critical distances and areas for both ships are much greater than the high wind speed cases. This is because the moderate wind speed leads the gas dispersion to be slow and smooth, thus creating a much higher level of flammability in the subject area. Therefore, it is concluded that the lower wind speed led to the more direct and longer critical distance and the wider area. However, under the same atmospheric conditions, the results for the VLCC tanker are more severe than the container ship in full load condition. The results of the analysis reveal that wind speed would have a significant influence on the expansion of the safety 
zone. Also, it may be worthwhile highlighting that the impact of the wind speed is also influenced to some extent by the surrounding conditions.

\subsection{Effect of wind directions}

Table 9 summarizes the results of the analysis to investigate the influence of wind directions on the fixed condition of the maximum leak rate $(466.0 \mathrm{~kg} / \mathrm{s}$ at $250 \mathrm{~mm}$ leak hole dia.) and the wind speed $(6 \mathrm{~m} / \mathrm{s})$. In addition to the Northerly wind direction, as a reference case, three other representative wind directions are considered in East, South and West. As with other cases, the direction of the leak is considered to be from West to East.

In the Easterly wind, it is found from the analysis that the critical distances and the areas are relatively small. This is because the wind direction is opposite to the direction of the gas discharge from the leakage hole. In the Southerly wind, the maximum critical distance turned out to be more extensive, but the critical area was set up less than in most of the Easterly wind scenarios. However, such trend was entirely invalid for the container ship in full load condition (congested space) in which the pile of on-board cargo is proven to be an object to hinder the gas spreading freely above the deck.

On the other hand, in the condition of the Westerly wind, the most critical results in both maximum distance and area are estimated. This is because the wind direction is the same as the direction of a gas leak. In other words, it can be said that the influence of the wind direction would be closely related to the direction of gas ejection. 
Table 9. Maximum critical distance under various wind directions for container shipVLCC tanker

\begin{tabular}{|c|c|c|c|c|c|c|}
\hline $\begin{array}{l}\text { Wind } \\
\text { Direction }\end{array}$ & $\begin{array}{l}\text { Leakage } \\
\text { Duration } \\
\text { [sec] }\end{array}$ & Geometry & $\begin{array}{c}\text { Maximum } \\
\text { Critical } \\
\text { Distance } \\
{[\mathrm{m}]}\end{array}$ & $\begin{array}{l}\text { Critical } \\
\text { Area } \\
{\left[\mathrm{m}^{2}\right]}\end{array}$ & Di & \\
\hline \multirow{4}{*}{ North } & \multirow{2}{*}{45} & $\begin{array}{l}\text { Container (Full } \\
\text { Load Cond) }\end{array}$ & 204 & 9,831 & \multicolumn{2}{|c|}{$0 \mathrm{~m} \quad 200 \mathrm{~m} \bullet$ Entrained Leak Point } \\
\hline & & VLCC & 266 & 25,478 & & \\
\hline & \multirow{2}{*}{90} & $\begin{array}{l}\text { Container Ship } \\
\text { (Full Loading) }\end{array}$ & 380 & 23,665 & & (Full L \\
\hline & & VLCC & 399 & 47,991 & & VLCC \\
\hline \multirow{4}{*}{ East } & \multirow{2}{*}{45} & $\begin{array}{l}\text { Container (Full } \\
\text { Load Cond) }\end{array}$ & 285 & 16,424 & \multirow{4}{*}{\multicolumn{2}{|c|}{$0 \overline{\mathrm{m}} 200 \mathrm{~m}$}} \\
\hline & & VLCC & 318 & 23,815 & & \\
\hline & \multirow{2}{*}{90} & $\begin{array}{l}\text { Container (Full } \\
\text { Load Cond) }\end{array}$ & 326 & 34,214 & & \\
\hline & & VLCC & 383 & 46,620 & & \\
\hline \multirow{4}{*}{ South } & \multirow{2}{*}{45} & $\begin{array}{l}\text { Container (Full } \\
\text { Load Cond) }\end{array}$ & 399 & 33,444 & \multirow{4}{*}{\multicolumn{2}{|c|}{ ᄀ $0000 \mathrm{~m}$}} \\
\hline & & VLCC & 287 & 19,963 & & \\
\hline & \multirow{2}{*}{90} & $\begin{array}{l}\text { Container Ship } \\
\text { (Full Loading) }\end{array}$ & 420 & 30,369 & & \\
\hline & & VLCC & 428 & 35,279 & & \\
\hline \multirow{4}{*}{ West } & \multirow{2}{*}{45} & $\begin{array}{l}\text { Container (Full } \\
\text { Load Cond) }\end{array}$ & 621 & 51,934 & \multirow{4}{*}{\multicolumn{2}{|c|}{$0 \stackrel{\mathrm{m}}{200 \mathrm{~m}}$}} \\
\hline & & VLCC & 663 & 75,520 & & \\
\hline & \multirow{2}{*}{90} & $\begin{array}{l}\text { Container (Full } \\
\text { Load Cond) }\end{array}$ & 691 & 92,073 & & \\
\hline & & VLCC & 853 & 121,254 & & \\
\hline
\end{tabular}

\subsection{Effect of geometric difference due to the loading condition}

To investigate the effect of the surrounding circumstances, unload condition (ballast condition) of the container ship is considered in the analysis additionally. The results in the full load condition are compared with those in the ballast condition. Table 10 summarizes the results.

For all wind direction cases in a leak duration of $90 \mathrm{~s}$, the container ship in ballast condition has more extensive maximum critical distance than the container ship in full load condition, except for the Southerly wind case where the on-board cargo plays a role in mitigating the impact of wind in the full load condition. Therefore, the computed results 
show that the open surrounding condition would generally be more critical than the congested surrounding condition regarding the formation of flammable gas in the event of an accidental leakage.

Table 10. Maximum critical distance under various wind directions for container shipcontainership

\begin{tabular}{|c|c|c|c|c|c|c|}
\hline $\begin{array}{c}\text { Wind } \\
\text { Direction }\end{array}$ & $\begin{array}{l}\text { Leakage } \\
\text { Duration } \\
\text { [sec] }\end{array}$ & Geometry & $\begin{array}{c}\text { Maximum } \\
\text { Critical } \\
\text { Distance } \\
{[\mathbf{m}]}\end{array}$ & $\begin{array}{l}\text { Critical } \\
\text { Area } \\
{\left[\mathrm{m}^{2}\right]}\end{array}$ & & \\
\hline \multirow{4}{*}{ North } & \multirow{2}{*}{45} & $\begin{array}{l}\text { Container (Full } \\
\text { Load Cond) }\end{array}$ & 204 & 9,831 & \multicolumn{2}{|c|}{$0 \overline{\mathrm{m}} \mathbf{2 0 0 \mathrm { m }} \cdot$ Entrained Leak Point } \\
\hline & & $\begin{array}{c}\text { Container } \\
\text { (Ballast Cond) } \\
\end{array}$ & 292 & 20,282 & & Container \\
\hline & \multirow{2}{*}{90} & $\begin{array}{l}\text { Container (Full } \\
\text { Load Cond) }\end{array}$ & 380 & 23,665 & & Container \\
\hline & & $\begin{array}{c}\text { Container } \\
\text { (Ballast Cond) }\end{array}$ & 381 & 47,980 & & (Ballast) \\
\hline \multirow{4}{*}{ East } & \multirow{2}{*}{45} & $\begin{array}{l}\text { Container (Full } \\
\text { Load Cond) }\end{array}$ & 285 & 16,424 & \multirow{4}{*}{\multicolumn{2}{|c|}{ 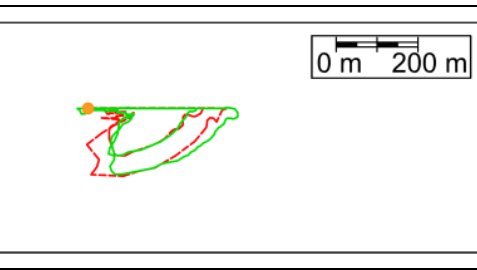 }} \\
\hline & & $\begin{array}{c}\text { Container } \\
\text { (Ballast Cond) } \\
\end{array}$ & 267 & 14,720 & & \\
\hline & \multirow{2}{*}{90} & $\begin{array}{l}\text { Container (Full } \\
\text { Load Cond) }\end{array}$ & 326 & 34,214 & & \\
\hline & & $\begin{array}{c}\text { Container } \\
\text { (Ballast Cond) } \\
\end{array}$ & 383 & 33,195 & & \\
\hline \multirow{4}{*}{ South } & \multirow{2}{*}{45} & $\begin{array}{l}\text { Container (Full } \\
\text { Load Cond) }\end{array}$ & 399 & 33,444 & \multirow{4}{*}{\multicolumn{2}{|c|}{2}} \\
\hline & & $\begin{array}{c}\text { Container } \\
\text { (Ballast Cond) } \\
\end{array}$ & 269 & 22,929 & & \\
\hline & \multirow{2}{*}{90} & $\begin{array}{l}\text { Container (Full } \\
\text { Load Cond) }\end{array}$ & 420 & 30,369 & & \\
\hline & & $\begin{array}{c}\text { Container } \\
\text { (Ballast Cond) } \\
\end{array}$ & 396 & 36,493 & & \\
\hline \multirow{4}{*}{ West } & \multirow{2}{*}{45} & $\begin{array}{l}\text { Container (Full } \\
\text { Load Cond) }\end{array}$ & 621 & 51,934 & \multirow{4}{*}{\multicolumn{2}{|c|}{$0 \mathrm{~m} 200 \mathrm{~m}$}} \\
\hline & & $\begin{array}{c}\text { Container } \\
\text { (Ballast Cond) } \\
\end{array}$ & 636 & 54,949 & & \\
\hline & \multirow{2}{*}{90} & $\begin{array}{l}\text { Container (Full } \\
\text { Load Cond) }\end{array}$ & 691 & 92,073 & & \\
\hline & & $\begin{array}{c}\text { Container } \\
\text { (Ballast Cond) }\end{array}$ & 726 & 93,909 & & \\
\hline
\end{tabular}

\section{Discussion on Determining the Safety Zone}

The present study has driven the fact that the range of the maximum critical distance and area across various accidental conditions would significantly vary. For the worst case scenario where the VLCC was subjected to the 90s LNG leak with the full leak (466.0 $\mathrm{kg} / \mathrm{s}$ at $250 \mathrm{~mm}$ leak hole diameter) in the Easterly wind at $6 \mathrm{~m} / \mathrm{s}$, the maximum critical 
distance and area were estimated at $853 \mathrm{~m}$ and 121,254 $\mathrm{m}^{2}$ respectively. For the container ship in full load condition, the safety zone could be as low as $75 \mathrm{~m}$ in distance and 473 $\mathrm{m}^{2}$ in the area when subjected to the $45 \mathrm{~s}$ LNG leak with small leak $(18.7 \mathrm{~kg} / \mathrm{s}$ at $50 \mathrm{~mm}$ leak hole diameter) condition with the Southerly wind at $6 \mathrm{~m} / \mathrm{s}$.

The results of the parametric studies show that the impact of the leakage amount would be significant in determining the safety zone as presenting both a high leakage rate and leakage duration result in more extensive critical distances and areas to be set in general. Results reveal that the wind speed also has a critical impact on extending the safety zone, but the tendency is inversely proportional; the higher wind speed led to smaller critical zones.

In short, this research recommends that if the LNG bunkering conditions are likely to face a high level of leakage rate and duration, extensive safety zones may be required; it implies that large-scale LNG bunkering may need more extensive safety zones. The reverse is also true. Table 11 and 12 summarize the research findings.

Table 11. Comparison of the case ships regarding the safety zone level under the various leak rates.

\begin{tabular}{|c|c|c|c|}
\hline Leak Hole Dia. & $\mathbf{2 5 0} \mathbf{~ m m}$ & $\mathbf{1 5 0} \mathbf{~ m m}$ & $\mathbf{5 0} \mathbf{~ m m}$ \\
\hline Leak Rate & Large & Normal & Small \\
\hline $\begin{array}{c}\text { Recommended } \\
\text { Safety Zone }\end{array}$ & Large & Mid & Small \\
\hline
\end{tabular}

Table 12. Comparison of the case ships regarding the safety zone level under the various wind speeds.

\begin{tabular}{|c|c|c|c|}
\hline Wind Speed & $\mathbf{6 ~ m / s}$ & $\mathbf{4 ~ m / s}$ & $\mathbf{2 ~ m / s}$ \\
\hline Extent & Harsh & Normal & Mild \\
\hline $\begin{array}{c}\text { Recommended } \\
\text { Safety Zone }\end{array}$ & Small & Mid & Large \\
\hline
\end{tabular}


Table 13. Comparison of the case ships regarding the safety zone level under the various wind directions.

\begin{tabular}{|c|c|c|c|}
\hline Wind Direction & $\begin{array}{c}\text { Wind in Opposite Direct. } \\
\text { to Gas Ejection }\end{array}$ & $\begin{array}{c}\text { Wind in Perpendicular } \\
\text { Direct. to Gas Ejection }\end{array}$ & $\begin{array}{c}\text { Wind in Same Direct. } \\
\text { to Gas Ejection }\end{array}$ \\
\hline Dispersion Effect & Small & Normal & Large \\
\hline $\begin{array}{c}\text { Recommended } \\
\text { Safety Zone }\end{array}$ & Small & Mid & Large \\
\hline
\end{tabular}

The results of the case studies to investigate the effects of wind directions reveal that the safety zone may need to be set broadly when the wind direction is in the same direction with that of the gas discharge from the leak hole. The results associated with the analysis of the impact of wind direction show that the surrounding condition (congested or open) has a critical influence on determining the level of the safety zone. If a gas leak is more likely to occur in an open space, the impact of gas dispersion will be severe. In this context, the general recommendations for establishing safety zones can be derived concerning the congestion ratio of the subject area where the leaked gas would spread as indicated in Table 14. Hence, the VLCC tanker with the lowest congestion ratio (Case ship 2) needs to establish a larger safety zone than that for the container ship (Case ship 1). Since the congestion ratio of the container ships in ballast condition is lower than that of the container ship in full load condition, a wider safety zone for the container ship in ballast condition needs to be recommended.

Table 14. Comparison of the case ships regarding the safety zone level under the different congestion ratios.

\begin{tabular}{|c|c|c|c|}
\hline Ship Geometry & $\begin{array}{c}\text { Target ship 1 } \\
\text { (Container- Full loading) }\end{array}$ & $\begin{array}{c}\text { Target ship 1 } \\
\text { (Container-Ballast) }\end{array}$ & $\begin{array}{c}\text { Target ship 2 } \\
\text { (VLCC) }\end{array}$ \\
\hline Congestion Ratio & High & Mid & Low \\
\hline $\begin{array}{c}\text { Recommended } \\
\text { Safety Zone }\end{array}$ & Small & Mid & Large \\
\hline
\end{tabular}




\section{Concluding Remarks and Further Studies}

The safety zone for enhancing the safety of LNG bunkering needs to be established along with the space between the LNG fuelled ship and the bunkering vessel. Given the lack of quantified guidelines for establishing the safety zone in industry practice, this paper delivers a remarkable research work providing ship designers, owners and rule-makers with an insight into the potential extent of flammable gas dispersion through the case studies with two representative ship types. The case studies dealt with the event of accidental LNG leaks in accordance with different bunkering conditions and accidental scenarios.

The main objective of the present study has been to examine the characteristics of leaked-gas dispersion in a ship to ship LNG bunkering and to determine a safety zone where the hazards can be minimized. In this context, research findings can be summarized that the geometry of the ships and the state of cargo shipment are important parameters in establishing the safety zone as gas congestion/ventilation are significantly affected by the surrounding conditions.

It is recommended to devise ways to reduce the leak rate and leak duration in the bunkering process so as to minimize the impact of accidental LNG release. It is also important to emphasize that the cargo loading should be carefully planned during the bunkering since the extent of gas spread may be affected by the ship's draught and the surrounding conditions exposed to the leaked gas. Wind speed and wind direction also need to be cautiously considered when determining the safe zone for LNG bunkering so that the hazards associated with leak-gas dispersion can be minimized.

As would be expected, research findings showed that the leakage amount is the most influential parameter in determining the safety zone. However, the core of research findings was placed on the fact that that the effect of the environmental conditions and 
ship geometry are also essential elements when establishing the safety zone. It is believed that this suggestion will contribute to enhancing the safety of LNG bunkering by establishing the safety zone in a more realistic way to supplement the shortcomings of the current practice where there has been a tendency to disregard or under-estimate such conditions.

It is obvious that the parameters affecting the hazards are the subject variables as applied in this paper. Meanwhile, the present study was aiming at obtaining the general trends and relationships between LNG bunkering parameters. Considering that the industry practice is lacking in terms of determining the safety zone for the LNG bunkering, it is believed that the insights developed in the paper may provide useful information as a corner stone. Nevertheless, in order to quantify the extent of safety zones in a more realistic way, a probabilistic analysis needs to be undertaken with a set of credible scenarios that represent all of the possible events involving extensive variations of influential parameters.

\section{Acknowledgements}

Part of the studies mentioned in this paper was supported by the Korean government through scholarships for one of the authors. The authors acknowledge the support of colleagues at Daewoo Shipbuilding \& Marine Engineering Co., Ltd. (DSME) for their valuable support, comments, and suggestions. They have contributed significantly to this study. The study was undertaken at the Korea Ship and Offshore Research Institute at Pusan National University which has been a Lloyd's Register Foundation Research Centre of Excellence. 


\section{References}

Arnet NML. 2014. LNG bunkering operations: establish probabilistic safety distances for LNG bunkering operations [Master's thesis, Department of Energy and Process Engineering]. Trondheim, Norway: Norwegian University of Science and Technology.

Aymelek M, Boulougouris EK, Turan O, Konovessis D. 2014. Challenges and opportunities for LNG as a ship fuel source and an application to bunkering network optimisation. Proceedings of International Conference on Maritime Technology and Engineering, 15-17 Oct, Lisbon, Portugal.

Bosch, C. J. H. van den, Weterings, R. A. P. M. 1996. Methods for the calculation of physical effects. Report TNO CPR14E.

CDI, ICS, OCIMF, SIGTTO. 2013. Ship to Ship Transfer Guide for Petroleum, Chemicals and Liquefied Gases. East Horsley, UK: Chemical Distribution Institute.

Crowl DA, Louvar JF. 2001. Chemical process safety (fundamentals with applications), 3rd ed. Boston(MA), USA: Pearson Education.

Davies PA, Fort E. 2014. LNG as a marine fuel: likelihood of LNG releases. Journal of Marine Engineering and Technology. 12(3):3-10.

DNV. 2012. Failure frequency guidance: process equipment leak frequency data for use in QRA. Oslo, Norway: Det Norske Veritas.

DNVGL. 2014. Liquefied natural gas (LNG) bunkering study. Oslo, Norway: Det Norske Veritas Germanischer Lloyd.

DNVGL. 2015. In focus: LNG as ship fuel (latest developments and projects in the LNG industry). Oslo, Norway: Det Norske Veritas Germanischer Lloyd.

Elsayed T, Leheta H. Shehadeh M. 2009. Multi-attribute risk assessment of LNG carriers during loading/offloading at terminals. Ships and Offshore Structures. 4(2):127-131.

Fan H, Cheng K, Wu S. 2017. CFD-based simulation of LNG release during bunkering and cargo loading/unloading simultaneous operations of a containership. Journal of Shipping and Ocean Engineering 7:51-58.

Gant S, Hoyes J. 2010. Review of FLACS version 9.0: dispersion modelling capabilities, Buxton, UK: Health and Safety Executive HSE Books.

Gexcon AS. 2017. FLACS version 10.5 user's manual. Bergen, Norway: Gexcon AS. 
Hjertager BH. 1984. Computer simulation of turbulent reactive gas dynamics. Journal of Modeling, Identification and Control. 5(4):211-236.

IGU. 2017. World LNG report. Barcelona, Spain: International Gas Union.

IMO. 2002. MSC/Circ.1023 guidelines for formal safety assessment (FSA) for use in the IMO rule-making process. London, UK: International Maritime Organization.

IMO. 2014. Third IMO greenhouse gas study-executive summary. London, UK: International Maritime Organization.

IMO. 2015. MSC 95/INF.17 information on incidents during bunkering of LNG.

London, UK: International Maritime Organization.

IMO. 2017. International Code of Safety for Ships using Gases or other Low-flashpoint Fuels (IGF Code). London, UK: International Maritime Organization.

ISO. 2015. Guidelines for systems and installations for supply of LNG as fuel to ships. Geneva, Switzerland: International Organization for Standardization. Jeong BW, Lee BS, Zhou P. 2017a. Quantitative risk assessment of fuel preparation room having high-pressure fuel gas supply system for LNG fuelled ship. Ocean Engineering. 137:450-468.

Jeong BW, Lee BS, Zhou P, Ha SM. 2017b. Evaluation of safety exclusion zone for LNG bunkering station on LNG-fuelled ships. Journal of Marine Engineering and Technology; p.1-24.

Lasse K. 2015. LNG (NG) fuelled shipping: experience and regulations. Haugesund, Norway: Norwegian Maritime Authority.

Launder BE, Spalding DB. 1974. The numerical computation of turbulent flows. Computer Methods in Applied Mechanics and Engineering. 3(2):269-289.

Patankar S. 1980. Numerical heat transfer and fluid flow. London, UK: CRC press. Pedersen HH, Midda P. 2012. Modelling of vented gas explosions in the CFD tool FLACS. Chemical Engineering Transactions. 26:357-362.

Schuler M. 2017. World's first purpose: built LNG bunkering vessel delivered. Available from: http:/gcaptain.com/worlds-first-dedicated-lng-bunkeringvessel-delivered-engie-zeebrugge/.

Ship-Technology. 2017. LNG bunkering vessel, Zeebrugge, Belgium. Available from: http://www.shi p-technology.com/projects/LNG-bunkering-vessel-zeebrugge. 
Ship \& Bunker. 2017. LNG bunker barge construction leaves shipyard with \$12.5million loss. Available from:

https://shipandbunker.com/news/world/909027-fleet-of-lng-fuelled-vessels-hits200.

Sun B, Guo K, Pareek VK. 2017. Hazardous consequence dynamic simulation of LNG spill on water for ship to ship bunkering. Process Safety and Environment Protection. 107:402-413. 